
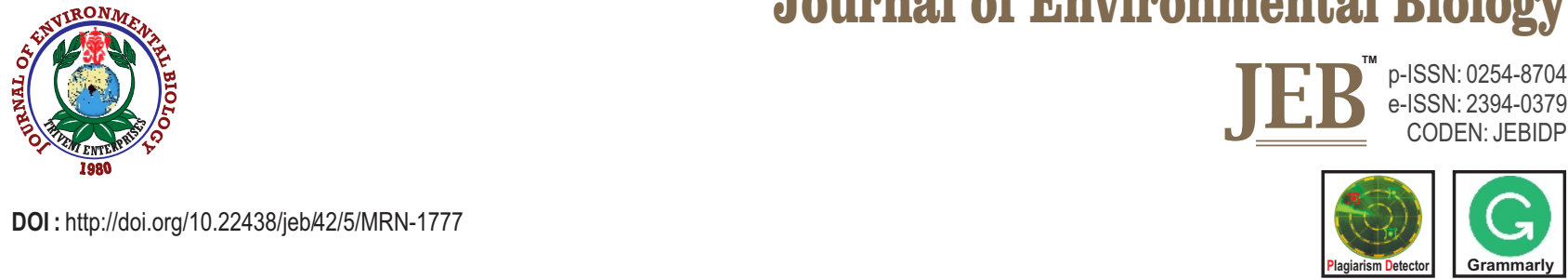

\title{
Response of contrasting bread wheat genotypes for heat and drought stress tolerance for rhizospheric soil properties
}

\author{
O.P. Ahlawat ${ }^{1 *}$, T. Chugh', K. Venkatesh', R. Tiwari', P. Sharma', S. Sheoran', R. Singh', H.M. Mamrutha', N.K. Arora ${ }^{3}$, G. Singh ${ }^{1}$ \\ and G.P. Singh ${ }^{1}$
}

${ }^{1}$ ICAR-Indian Institute of Wheat and Barley Research, Karnal-132 001, India

${ }^{2}$ Dept. of Microbiology, COBS\&H, Punjab Agricultural University, Ludhiana-144 004, India

${ }^{3}$ ICAR-Central Soil Salinity Research Institute, Karnal-132 001, India

*Corresponding Author Email : om.ahlawat@icar.gov.in

\begin{abstract}
Aim: The study aimed at investigating differential response of contrasting bread wheat genotypes for heat and drought stress towards changes in chemical and microbial components of rhizospheric soil for developing climate resilient wheat varieties.

Methodology: Rhizospheric soils were studied for changes in $\mathrm{pH}$, electrical conductivity, cations, anions, micro-elements, majorelements, organic carbon and organic matter, and plant growth promoting rhizobacteria(PGPRs) abundance at booting and anthesis stages of growth in four contrasting genotypes during 2017-18 and 2018-19 crop seasons.

Results: The contrasting genotypes (HD2967 and WH730) for heat tolerance exhibited significant interaction between genotype and stage of growth for $\mathrm{Na}^{+}, \mathrm{K}^{+}$and nitrogen, while genotypes (HUW468 and C306) for drought tolerance exhibited it for available nitrogen only. Significant difference for $\mathrm{Ca}^{2+}, \mathrm{Mg}^{2+}$, iron, manganese, nitrogen and potassium levels were recorded in drought stress related genotypes at two stages of growth. The heat tolerant genotype showed 2.54 and 10.67 folds enhancement in population of $\mathrm{N}_{2}$ fixing and spore forming bacteria at anthesis compared to sensitive genotypes, while drought tolerant genotype showed 1.51, 1.07 and 6.26 folds in P-solubilizing, $\mathrm{N}_{2}$ fixing and general bacterial abundance.

Interpretation: Contrasting genotypes for heat and drought stresses responded differently for chemical properties and abundance of PGPRs in rhizospheric soils.

Key words: Abiotic stress, Plant growth promoting rhizobacteria, Rhizospheric soil, Wheat genotypes

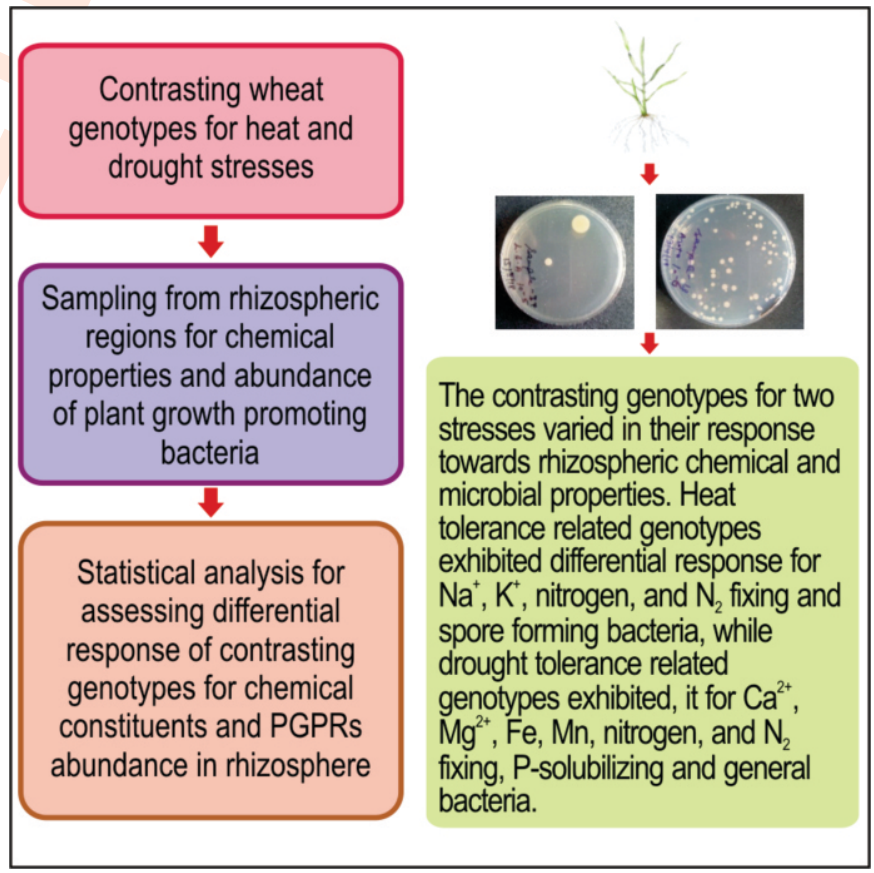




\section{Introduction}

The rhizosphere is intriguingly complex and dynamic (Philippot et al., 2013), and changes in it are continually renewed by root growth and exudates from the roots (Brasil et al., 2011). A good understanding of the processes undergoing in it, is vital for maintaining soil health and sustained crop production (Morrissey et al., 2004). Plant roots release a large number of carbon containing compounds known as rhizodeposits. These are comprised of mainly nutrients, exudates, border cells, and mucilage. The release of rhizodeposits by the plants is influenced by several factors like, genotype, species, and the age and stage of growth (Lemanceau et al., 2017; Qiao et al., 2017). Abiotic factors, specially drought affects the concentration and accumulation patterns of $\mathrm{Ca}, \mathrm{Fe}, \mathrm{Mg}, \mathrm{Mo}$ and $\mathrm{S}$ in the plants and soil (Sardans et al., 2008). Similarly, the microbial community structure of rhizosphere is affected by the genotypes, soil types, field management practices and developmental stage of the plant (Brasil et al., 2011; Philippot et al., 2013; Qiao et al., 2017; Berlanas et al., 2019). There are also some contradiction to this, and in one such study, the contrasting maize genotypes for P-use efficiency did not show variation in their rhizosphere properties (Brasil et al., 2011), while in another study with cotton cultivars, the community structure of the rhizosphere bacteria was found to be affected by the developmental stages of the plant (Qiao et al., 2017). In another study on Boechera stricta (Brassicaceae), the host genetic control was recorded on leaves microbiome but not on roots microbiome. In case of grapevine rootstock genotypes, the mature vineyard were found associated with different rhizosphere microbiomes (Berlanas et al., 2019).

Among abiotic stresses, drought and heat stress are the major one, and are going to worsen with time under continuously changing climatic conditions. Both stresses affect plant growth by inducing changes at all levels leading to severe losses in crop productivity (Sallam et al., 2019). Till now, efforts have been made to understand drought or heat tolerance in wheat, by focusing the physiology, breeding and genetic research (Sallam et al., 2019). The underground component of plant, mainly the rhizospheric region has received very little attention for abiotic stress mitigation in wheat. However, few publications have come up during last decade, highlighting the role of rhizospheric interactions and micro environment, including PGPRs in mitigating the adverse effects of heat and drought stresses in wheat (Kasim et al., 2013; Gontia-Mishra et al., 2016). The exudates from plant roots not only act as a food source for microbes but also act as chemo-attractant for microbes (Danhorn and Fuqua, 2007). In return, the rhizospheric microbes help in uptake of nutrients and plant growth (Jha et al., 2012). The PGPRs are also adapted to stressed conditions, and have been reported to help plants withstand abiotic stresses by altering the responses at physiological and genes level (Kaushal et al., 2016).

Maintaining crop productivity in cereals and mainly in wheat is of utmost importance for the food and nutrition security of the growing population, more so under changing climatic conditions. The aforesaid challenge can only be met by multifaceted strategies including breeding for climatic resilient varieties, use of molecular tools and applying management practices like modulation of underground soil conditions. In order to compliment the efforts of wheat breeders, the present study was envisaged to study the role of contrasting bread wheat genotypes for two major abiotic stresses towards inducing desirable changes in chemical constituents and PGPRs abundance in their rhizospheric soil, and use the generated information for future breading programs and augmenting the field conditions to mitigate the adverse effects of abiotic stresses.

\section{Materials and Methods}

Sample collection: The rhizospheric soil samples were taken from four contrasting bread wheat (Triticum aestivum) genotypes, viz., WH730-heat tolerant, HD2967-heat sensitive, C306drought tolerant, and HUW468-drought sensitive, first by removing surface debris, cutting plants $5 \mathrm{~cm}$ above soil surface and removing roots along with surrounding soil in $10 \mathrm{~cm}$ dia. and up to $15 \mathrm{~cm}$ depth using auger. Samples for heat stress related genotypes were taken from plants planted in Completely Randomized Block Design (CRBD) under field -and Temperature Controlled Phenotypic Facility at research farm of ICAR-IIWBR, Karnal, while for drought stress related genotypes; these were taken from genotypes planted in CRBD under rain-fed condition at the same farm. Three replicated samples each, were taken at booting and anthesis stages of plant growth for each genotype during 2017-18 and 2018-19 crop seasons. The samples collected in aluminium envelopes were brought to laboratory in ice boxes, and were divided in to two lots; the soil loosely attached to roots (easily removable by shaking) was used for chemical analysis, while soil tightly adhered to roots (removed by using sterilized brush) was used for isolation of PGPRs. Air and soil temperatures were recorded at all sampling dates and locations, and these varied between stages of growth and contrasting genotypes for heat and drought stresses, as sampling was done as per stages of plant growth falling on different dates during both crop seasons.

Chemical analysis of rhizospheric soil samples: The loosely bound soils to the roots of genotypes at two stages of growth during both crop seasons were first dried under shade, grinded and sieved. These were analyzed for $\mathrm{pH}$, electrical conductivity, cations $\left(\mathrm{Na}^{+}, \mathrm{K}^{+}, \mathrm{Ca}^{2+}\right.$ and $\left.\mathrm{Mg}^{2+}\right)$, anions $\left(\mathrm{CO}_{3}^{2-}, \mathrm{HCO}_{3}{ }^{\circ}, \mathrm{Cl}\right.$ and $\left.\mathrm{SO}_{4}{ }^{2}\right)$, minor elements $(\mathrm{Fe}, \mathrm{Mn}, \mathrm{Zn}$ and $\mathrm{Cu})$, major elements ( $\mathrm{N}, \mathrm{P}$, $\mathrm{K}$ and $\mathrm{S}$ ), organic carbon (OC) and organic matter (OM). Three replications were kept for each assay. For analysis of $\mathrm{pH}$, electrical conductivity, cations and anions, $25 \mathrm{~g}$ soil sample was taken in $250 \mathrm{ml}$ conical flask and $50 \mathrm{ml}$ distilled water was added. It was put on mechanical shaker for $2 \mathrm{hr}$. The suspension was filtered through Whatman No. 1 filter paper and used for analysis. $\mathrm{pH}$ and $\mathrm{EC}$ were determined following the protocol of Jackson 
(1973). Sodium and potassium ions were determined with improvised flame photometric method of Richards (1954). Calcium and magnesium ions were determined by versenate titration method of Bhargava (2003), where titration was done with $0.01 \mathrm{~N}$ EDTA using $0.5 \%$ EBT (Eriochrome black T) as indicator. Carbonate $\left(\mathrm{CO}_{3}^{2-}\right)$ and bicarbonate $\left(\mathrm{HCO}_{3}^{-}\right)$were analysed by titration with $0.01 \mathrm{~N} \mathrm{H}_{2} \mathrm{SO}_{4}$ by using phenolphthalein and methyl orange, respectively as indicators by improvised method of Richards (1954). Chloride $\left(\mathrm{Cl}^{-}\right)$was assayed by argentometric method of Bhargava (2003). Sulphate $\left(\mathrm{SO}_{4}^{2-}\right)$ was determined with turbidity method of Chesnin and Yien (1950) using spectrophotometer at $420 \mathrm{~nm}$. Fe, Mn, Zn and Cu were determined by taking $15 \mathrm{~g}$ soil sample in a flask along with $30 \mathrm{ml}$ diethylene triamine pentaacetic acid (DTPA). The samples were analysed by Flame Atomic Absorption Spectroscopy method of Lindsway and Norvell (1978). Among macro-nutrients (N, P, Kand S), potassium was analyzed by Flame Photometry method of Richards (1954). Nitrogen was determined by Kjeldahl method (Gee and Bauder, 1986). Phosphorus was analyzed by the spectrophotometry method of Kuo et al. (1996) at $882 \mathrm{~nm}$. Sulphur was again determined by spectrophotometry method of Williams and Steinbergs (1959) at $420 \mathrm{~nm}$. Organic carbon was analysed by wet-oxidation method of Nelson and Sommers (1996), while organic matter by the method of Walkley and Black (1934).

Plant growth promoting rhizobacteria (PGPRs) dynamism in rhizospheric soil samples: The samples of soil tightly bound to roots were processed for enumeration of different types of bacteria in the rhizosphere. Specific growth medium viz., Pikovskayas Agar, Norris Glucose Nitrogen Free, Beijerinckia, Ashbys Glucose Agar, Azotobacter Agar (Mannitol), Luria Bertani Agar Miller, Cetrimide Agar Base and NutrientAgar from Hi-Media Laboratories were used for quantitative enumeration of Phosphate-solubilizing bacteria (PSB), nitrogen fixing chemoheterotrophic bacteria (NFB), Beijerinckia spp., glucose utilizing Azotobacter spp., mannitol positive Azotobacter spp., spore forming bacteria (SFB), Pseudomonas aeruginosa and total bacterial count (TBC), respectively. Bacteria were isolated using standard protocol of dilution and plating by the method of Wilson (1922).

Statistical analyses: The data was analyzed for 3-way analysis of variance and ranking of treatments using Tukey's Studentized Range Test (TSRT) at 1, 5 and $10 \%$ level of significance. General Linear Model (GLM) Procedure in SAS®9.3 version 6.1.7061 for Windows (SAS Institute Inc., 2012) was used for statistical analysis. For comparing results, treatments viz; growth stage, genotypes, year were included in the model as fixed factors and replications were treated as random effects.

\section{Results and Discussion}

Rhizosphere soil samples analysis revealed significant difference in $\mathrm{pH}$ values between two years of sampling and two growth stages. $\mathrm{pH}$ enhancement from booting to anthesis stage was comparatively higher in heat tolerant genotype WH730 as compared to sensitive genotype HD2967. Also, there was significant interaction between stage of growth and crop season (Table 1). Among cations, $\mathrm{Na}^{+}$and $\mathrm{K}^{+}$showed significant interaction between stage of growth and genotype (Table 1). The level of $\mathrm{Na}^{+}$increased from booting to anthesis stage in heat tolerant genotype during both crop seasons. Conversely it decreased in sensitive genotype (Fig. 1A). Furthermore, the level of $\mathrm{K}^{+}$changed insignificantly from booting to anthesis stage in tolerant genotype during two crop seasons, while it decreased significantly in sensitive genotype (Fig. 1B). The level of $\mathrm{Mg}^{2+}$ decreased from booting to anthesis stage in sensitive genotype during both seasons, while, it increased in tolerant genotype WH730 during 2017-18, and was higher than in sensitive genotype at anthesis during both years (Fig. 1D). Among anions, $\mathrm{Cl}^{-}$showed significant difference at two stages of growth (Table 1), while its level was higher at booting compared to anthesis stage in both genotypes. Copper was significantly higher in heat sensitive genotype compared to tolerant genotype at both growth stages. The level of available iron differed insignificantly from booting to

Table 1 : Analysis of variance for effect of genotype and stage of growth on wheat rhizosphere chemical properties in heat sensitive and tolerant genotypes

\begin{tabular}{|c|c|c|c|c|c|c|c|c|c|}
\hline \multirow[t]{2}{*}{ Factors } & \multirow[t]{2}{*}{$\mathrm{pH}$} & \multicolumn{3}{|c|}{ Cations } & \multirow{2}{*}{$\frac{\text { Anions }}{\mathrm{Cl}^{-}}$} & \multicolumn{2}{|c|}{ Micro-elements } & \multicolumn{2}{|c|}{ Major-elements } \\
\hline & & $\mathrm{Na}^{+}$ & $\mathrm{K}^{+}$ & $\mathrm{Mg}^{2+}$ & & $\mathrm{Fe}$ & $\mathrm{Cu}$ & $\mathbf{N}$ & S \\
\hline Stage & $0.0557^{*}$ & 0.4198 & 0.3515 & 0.5645 & $0.0833^{*}$ & 0.798 & 0.1616 & 0.8218 & $0.0876^{*}$ \\
\hline Genotype & 0.2667 & 0.816 & 0.7696 & 0.5645 & 0.937 & 0.853 & $0.0995^{\star}$ & 0.4879 & 0.6793 \\
\hline Year & $0.0476^{* *}$ & $0.0014^{* * *}$ & $0.028^{* *}$ & 0.7001 & $0^{* * *}$ & $0.0024^{\star * *}$ & $0^{* \star *}$ & $0^{* \star *}$ & $0.0002^{* * *}$ \\
\hline Genotype:Year & 0.112 & 0.2321 & 0.1936 & $0.0465^{\star *}$ & 0.937 & 0.8502 & 0.3041 & 0.8756 & 0.6268 \\
\hline Stage: Genotype & 0.8775 & $0.0252^{\star *}$ & $0.0534^{*}$ & 0.1362 & 0.39 & 0.5665 & 0.7589 & $0.0049^{* * *}$ & 0.6027 \\
\hline Stage:Year & $0.0945^{*}$ & 0.2217 & 0.7206 & 0.3414 & 0.6933 & 0.983 & 0.3181 & 0.4603 & 0.1231 \\
\hline Stage: Genotype: Year & 0.3579 & 0.428 & 0.1739 & 0.2565 & 0.191 & 0.7868 & 0.1884 & 0.397 & 0.6586 \\
\hline
\end{tabular}

${ }^{a}$ EC-Electrical conductivity, ${ }^{b}$ stage (booting and anthesis), ${ }^{\circ}$ genotype (heat sensitive HD2967 and heat tolerant WH730), ${ }^{d}$ year (crop season $2017-18$ and 2018-19); ${ }^{*}$ significant at $10 \%$ probability, ${ }^{* *}$ significant at $5 \%$ probability, ${ }^{* * *}$ significant at $1 \%$ probability 
anthesis stage in heat sensitive genotype HD2967, while, it decreased in tolerant genotype during both crop seasons (Fig. 1E). Among major-elements, nitrogen exhibited significant interaction between stage of growth and genotypes (Table 1).
Nitrogen levels in rhizosphere increased from 139.21 and 116.5 $\mathrm{kg} \mathrm{ha}^{-1}$ at booting to 163.23 and $123.73 \mathrm{~kg} \mathrm{ha}^{-1}$ at anthesis in sensitive genotype HD2967 during 2017-18 and 2018-19, respectively, while it decreased from 163.35 and $133.3 \mathrm{~kg} \mathrm{ha}^{-1}$ at

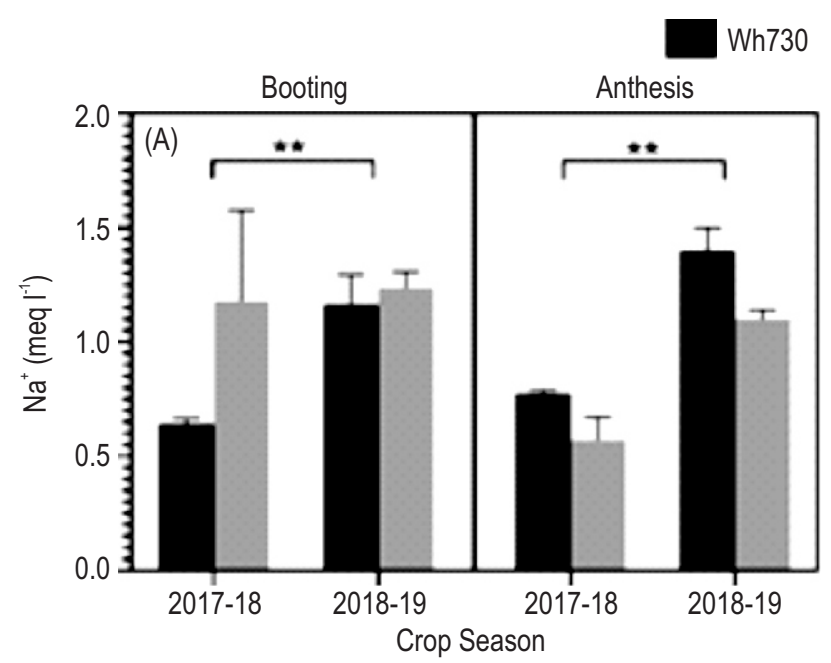

Hd2967
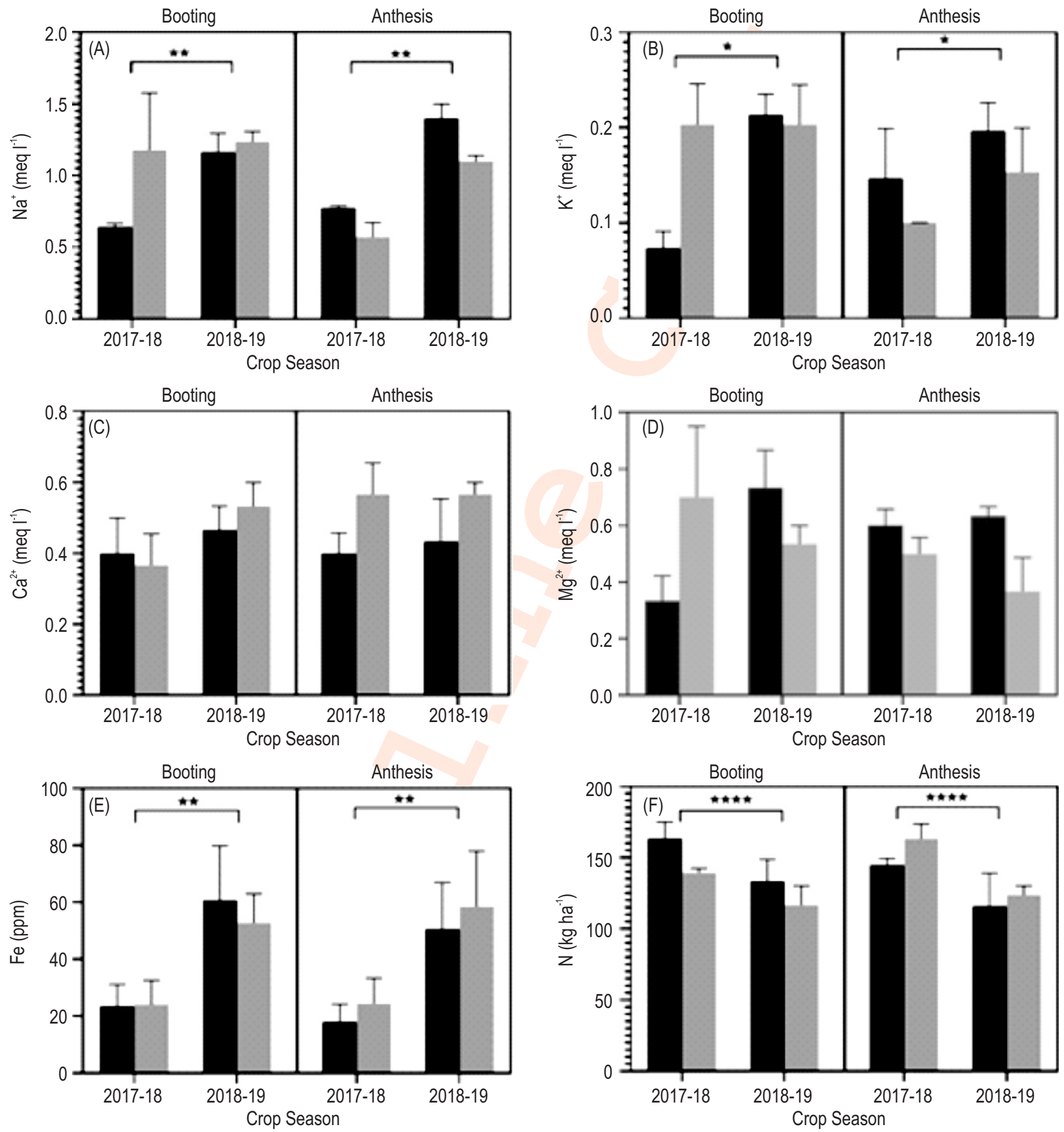

Fig. 1 : Effect of crop season, stage of growth and genotype on chemical properties of rhizosphere in contrasting wheat genotypes for heat tolerance: (a) $\mathrm{Na}^{+}$level; (b) $\mathrm{K}^{+}$level; (c) Ca ${ }^{2+}$ level; (d) $\mathrm{Mg}^{2+}$ level; (e) iron level and (f) nitrogen level. ${ }^{* * * *},{ }^{* * *}{ }^{* *}$ and ${ }^{* *} \mathrm{p}$ value at $0.0001,0.0002,0.0021$ and 0.12 probabilities, respectively 
booting to 144.77 and $115.9 \mathrm{~kg} \mathrm{ha}^{-1}$ at anthesis in tolerant genotype WH730 (Fig. 1F). The remaining parameters did not show significant differences with respect to stage of growth, genotypes, year or their interaction.

In genotypes for drought tolerance, there was significant interaction between year $\times$ genotype and stage $\times$ year $\times$ genotype for EC, thereby revealing differential response for these factors. EC decreased from booting to anthesis stage in sensitive genotype HUW468, while it increased in tolerant genotype C306. Among cations, $\mathrm{Ca}^{2+}$ showed significant enhancement from booting to anthesis stage in tolerant genotype (C306), while it was constant in sensitive genotype (HUW468) during both crop seasons (Fig. 2A). Magnesium showed reverse trend, as it increased from booting to anthesis stage in sensitive genotype and decreased in tolerant genotype during both years (Fig. 2B). It also showed significant difference between stages of growth and genotypes (Table 2). All three anions $\left(\mathrm{Cl}^{-}, \mathrm{HCO}_{3}{ }^{-}\right.$and $\mathrm{SO}_{4}{ }^{2-}$ ) did not show significant difference between growth stages or genotypes or their interaction and thus were non-indicative. Among microelements, iron exhibited significant difference between growth stages in contrasting genotypes, and it increased significantly from booting to anthesis stage in both genotypes (Fig. 2C). The enhancement was significantly higher in drought sensitive genotype HUW468 during 2018-19 crop season. Similarly, the difference in manganese levels was significant between two stages of growth in two genotypes, and it also showed significant interaction between year $x$ genotype and stage $x$ year $x$ genotype, thus suggesting potential role in managing stress levels of wheat genotypes (Table 2). Among major-elements, both nitrogen and potassium exhibited significant difference between stages of growth, while $\mathrm{N}$ also showed significant interaction between genotypes, stage $\times$ year, stage $\times$ genotype and stage $\times$ year $\times$ genotype (Table 2). Available nitrogen increased from 145.31 and $156.34 \mathrm{~kg} \mathrm{ha}^{-1}$ at booting to 152.98 and $163.03 \mathrm{~kg} \mathrm{ha}^{-1}$ at anthesis stage in sensitive (HUW468) and tolerant genotypes (C306), respectively during 2017-18 cropping season (Fig. 2E).
Conversely, the potassium level was much higher in sensitive genotype compared to tolerant genotype, and it increased from booting to anthesis stage in both genotypes (Fig. 2F). Organic carbon and organic matter did not show significant difference between growth stages and genotypes.

Among different PGPRs, nitrogen fixing bacteria showed significant difference between contrasting genotypes for both stresses. It was highly significant between heat tolerance related genotypes. In genotypes for drought, significant differences were recorded between growth stages and genotypes, and significant interaction between genotype $\times$ growth stages. The colony forming units were significantly higher in drought sensitive genotype compared to tolerant genotype at booting stage, which decreased nearly 8-145 folds in two genotypes at anthesis stage (Table 3). The decrease was significantly higher in drought sensitive genotype compared to tolerant genotype. These genotypes also showed significant difference between stages of growth for phosphate solubilizing bacteria, where the colony forming units decreased 42.98 folds from booting to anthesis stage in sensitive genotype HUW468, while, it increased 4.64 folds in tolerant genotype C306 (Table 3). Spore former colony forming units only showed significant interaction between stages of growth $\times$ genotype in contrasting genotypes for heat stress. The colony forming units decreased 9.36 folds from booting to anthesis stage in heat sensitive genotype, while it increased 6.49 folds in heat tolerant genotype (Table 3). Pseudomonas sp. was recorded only at anthesis stage in heat tolerant genotype (WH730) and at both stages in drought tolerant genotype (C 306). General bacterial count showed significant differences between stage of growth and contrasting genotypes, and interaction between stage $\times$ genotype in drought related genotypes. The CFUs decreased 104.69 folds in drought sensitive genotype HUW468 from booting to anthesis stage, while it increased in tolerant genotype C306 (Table 3).

Rhizosphere is the most active part of soil, and the processes undergoing in it have the ability to mitigate the adverse

Table 2: Analysis of variance for effect of genotype and stage of growth on wheat rhizosphere chemical properties in drought sensitive and tolerant genotypes

\begin{tabular}{|c|c|c|c|c|c|c|c|}
\hline \multirow[t]{2}{*}{ Factors } & \multirow{2}{*}{$\begin{array}{l}\text { Electrical } \\
\text { conductivity }\end{array}$} & \multicolumn{2}{|c|}{ Cations } & \multicolumn{2}{|c|}{ Micro-elements } & \multicolumn{2}{|c|}{ Major-elements } \\
\hline & & $\mathrm{Ca}^{2+}$ & $\mathrm{Mg}^{2+}$ & $\mathrm{Fe}$ & $\mathrm{Mn}$ & $\mathbf{N}$ & $\mathrm{K}$ \\
\hline Stage & 0.4105 & $0.0955^{*}$ & $0.0278^{\star *}$ & $0.04^{\star *}$ & $0.0046^{\star \star *}$ & $0.0003^{* * *}$ & $0.0105^{\star *}$ \\
\hline Year & $0^{* * *}$ & 0.4714 & $0^{\star \star *}$ & $0.0035^{\star * *}$ & $0.0038^{\star * *}$ & $0.0001^{* * *}$ & $0^{\star \star *}$ \\
\hline Genotype & 0.7195 & 0.7153 & $0.0278^{* *}$ & 0.3586 & 0.691 & $0.0001^{* * *}$ & 0.2208 \\
\hline Year: Genotype & $0.068^{*}$ & 0.2897 & $0.0072^{\star * *}$ & 0.2749 & $0.0527^{*}$ & $0.0019^{* * *}$ & $0.0176^{* *}$ \\
\hline Stage:Year & 0.5524 & 0.7153 & 0.3972 & 0.1456 & 0.7431 & $0.0003^{* * *}$ & 0.2317 \\
\hline Stage: Genotype & 0.2096 & 0.169 & 0.1114 & 0.1709 & 0.4907 & $0.0011^{* * *}$ & 0.9808 \\
\hline Stage:Year: Genotype & $0.09 * 99$ & 1 & 0.1114 & 0.1413 & $0.0762^{*}$ & $0.0004^{* * *}$ & 0.3294 \\
\hline
\end{tabular}

${ }^{a}$ EC-Electrical conductivity, ${ }^{b}$ stage (booting and anthesis), ${ }^{c}$ genotype (drought sensitive HUW468 and drought tolerant C306), 'year (crop season $2017-$ 18 and 2018-19), ${ }^{*}$ significant at $10 \%$ probability, ${ }^{* *}$ significant at $5 \%$ probability, ${ }^{* * *}$ significant at $1 \%$ probability 


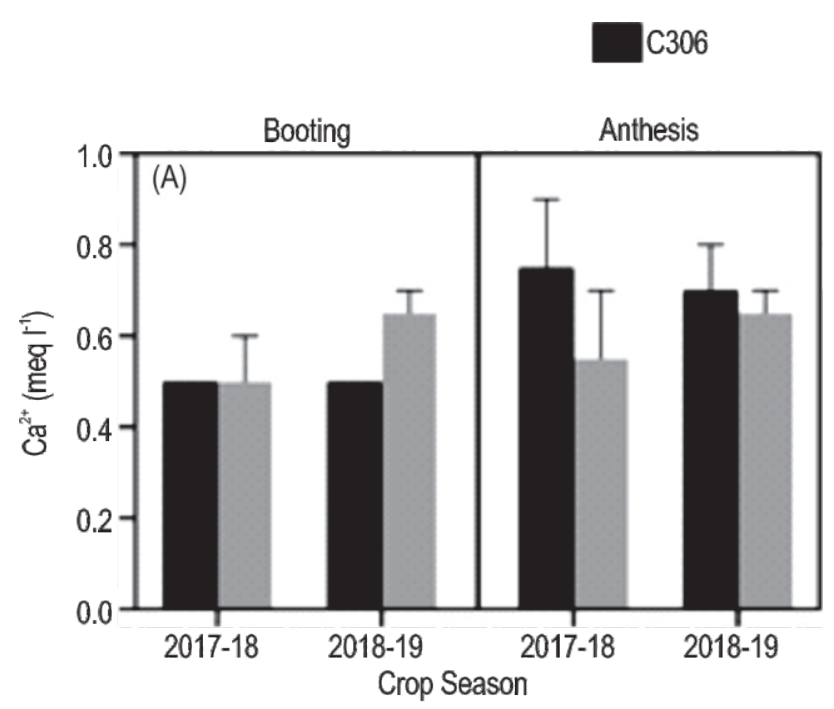

HUW468
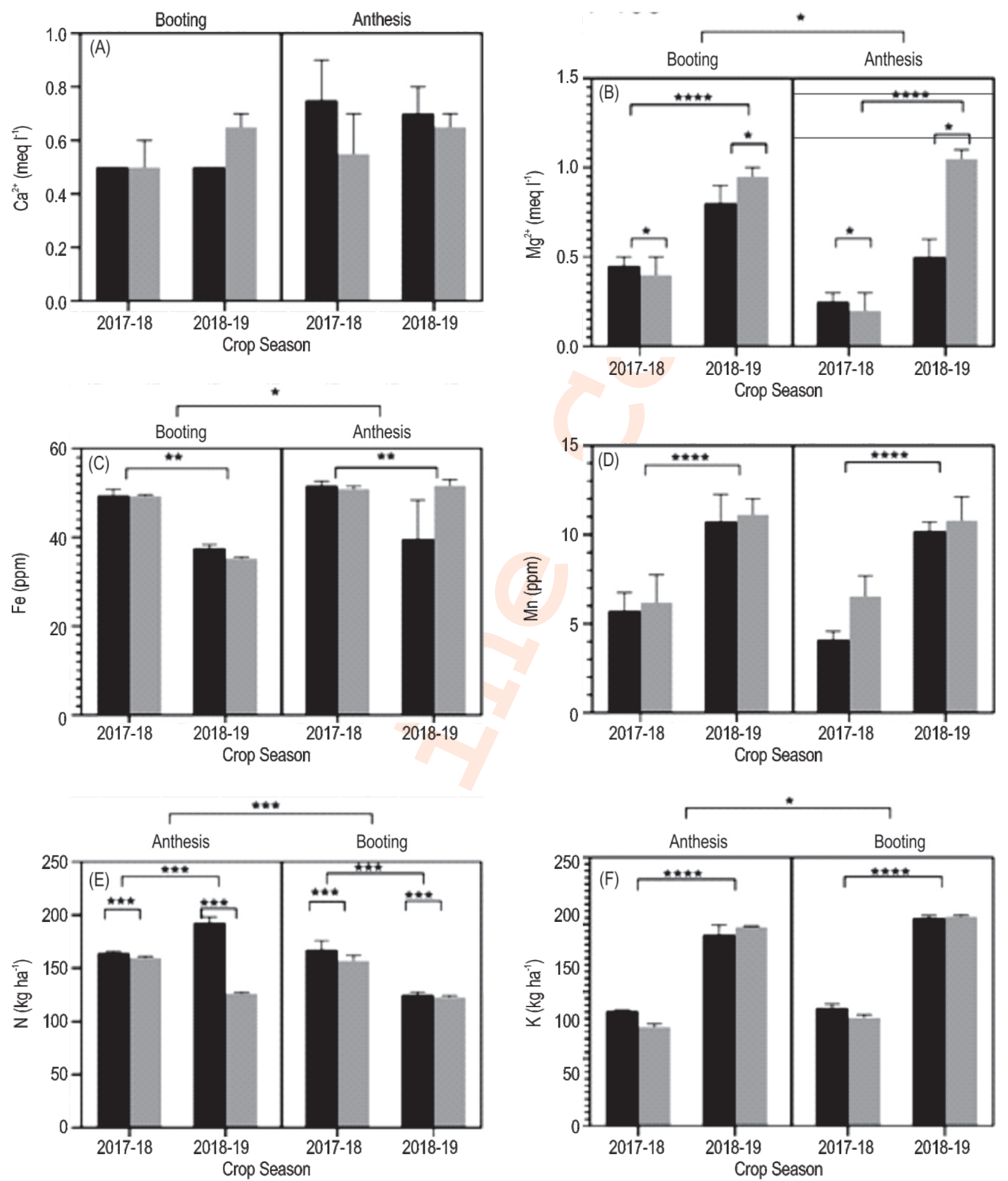

Fig. 2 : Effect of crop season, stage of growth and genotype on chemical properties of rhizosphere in contrasting wheat genotypes for drought tolerance: (a) Ca ${ }^{2+}$ level; (b) Mg ${ }^{2+}$ level; (c) iron level; (d) manganese level; (e) nitrogen level and (f) potassium level. ${ }^{* * *},{ }^{* * *},{ }^{* *}$ and ${ }^{*} p$ value at $0.0001,0.0002$, 0.0021 and 0.12 probabilities, respectively. 
Table 3 : Rhizosphere bacterial counts of PGPRs showing differential response in contrasting wheat genotypes for heat and drought stresses at two stages of growth $\left(10^{6} \mathrm{~g}^{-1}\right.$ of soil)

\begin{tabular}{|c|c|c|c|c|c|c|c|c|}
\hline \multirow[t]{3}{*}{ PGPRs } & \multicolumn{4}{|c|}{ Heat } & \multicolumn{4}{|c|}{ Drought } \\
\hline & \multicolumn{2}{|c|}{ Booting } & \multicolumn{2}{|c|}{ Anthesis } & \multicolumn{2}{|c|}{ Booting } & \multicolumn{2}{|c|}{ Anthesis } \\
\hline & HD2967 & WH730 & HD2967 & WH730 & HUW468 & C306 & HUW468 & C306 \\
\hline $\begin{array}{l}\text { Nitrogen fixing bacteria } \\
\text { (chemoheterotroph) }\end{array}$ & $2.22^{\mathrm{aA}}$ & $17.4^{\mathrm{aB}}$ & $7.44^{\mathrm{aA}}$ & $18.88^{\mathrm{aB}}$ & $628.88^{\mathrm{aA}}$ & $39.61^{\mathrm{aB}}$ & $4.33^{\mathrm{bA}}$ & $4.99^{\mathrm{bB}}$ \\
\hline Phosphate solubilizing bacteria & - & - & - & - & $439.26^{\mathrm{aA}}$ & $3.33^{\mathrm{aB}}$ & $10.22^{\mathrm{bA}}$ & $15.44^{\mathrm{bB}}$ \\
\hline Spore former bacteria & $75.92^{\mathrm{AA}}$ & $13.33^{\mathrm{aB}}$ & $8.11^{\mathrm{aA}}$ & $86.55^{\mathrm{aB}}$ & - & - & - & - \\
\hline General bacterial count & - & - & - & - & $1861.11^{1 \mathrm{~A}}$ & $14.22^{\mathrm{aB}}$ & $17.78^{\mathrm{bA}}$ & $76.00^{\mathrm{bB}}$ \\
\hline
\end{tabular}

* Same alphabetical letter after values indicate non-significance at $p=0.05$

effects of climate change to meet the growing food demand (McNear, 2013). In present study, the contrasting genotypes for heat stress exhibited significant difference for $\mathrm{pH}$ and sulphur between two stages of growth, while only for $\mathrm{Cl}$ and $\mathrm{Cu}$ between genotypes, and significant interactions between stage of growth $\times$ genotype for $\mathrm{Na}^{+}, \mathrm{K}^{+}$and $\mathrm{N}$. The two contrasting genotypes for drought stress behaved little differently and mainly differed for $\mathrm{EC}, \mathrm{Ca}^{2+}, \mathrm{Mg}^{2+}, \mathrm{Fe}, \mathrm{Mn}, \mathrm{N}$ and $\mathrm{K}$ between two stages of growth. In concurrence to present study, the earlier studies have also proved the influence of plant's root exudates on rhizosphere chemical properties, and the type and amount of root exudates released are governed by the plant species, edaphic and climactic conditions, and the microbial community in rhizosphere (Jones et al., 2009; McNear, 2013). Further, the pH of rhizospheric soil is influenced by the forms of nitrogen present in soil, as the presence of $\mathrm{NH}_{4}{ }^{+}$leads to decrease in $\mathrm{pH}$, while $\mathrm{NO}_{3}{ }^{-}$leads to enhancement in pH (Jones et al., 2009). In the present case, an increase in $\mathrm{pH}$ from booting to anthesis stage in heat tolerant genotype WH730, and decrease in sensitive genotype HD2967 can be attributed to the enhanced level of nitrate form of nitrogen at anthesis stage in heat tolerant genotype compared to heat sensitive genotype. However, an increased level of total available nitrogen from booting to anthesis stage in sensitive genotype and decreased level in tolerant genotype can be attributed to nitrogenuse efficiency of heat tolerant genotype up to anthesis stage of growth, which resulted in lesser nitrogen in rhizosphere (Sairam, 1994). Similarly, under phosphate deficiency plant roots exude malic and citric acids into the rhizosphere leading to reduced rhizosphere $\mathrm{pH}$, which again depend upon plant type (dicot vs. monocot), species and genotype (McNear, 2013). The slight increase in $\mathrm{pH}$ between growth stages in heat tolerant genotype reflect that its roots release lesser or no organic acids for phosphate solubilization during anthesis stage or it may have utilized majority of phosphorus up to booting stage. It is also supported by decrease in available phosphorus from booting (68 $\left.\mathrm{kg} \mathrm{ha}^{-1}\right)$ to anthesis stage (55.73 $\left.\mathrm{kg} \mathrm{ha}^{-1}\right)$ in tolerant genotype. Conversely, the heat sensitive genotype may have started releasing organic acids from booting stage onward, leading to decrease in rhizosphere $\mathrm{pH}$ at anthesis along with enhanced availability of phosphorus in rhizosphere. The findings of this study are in concurrent with the findings of Rengel (2005) in phosphorus-efficient Phaseolus vulgaris genotypes. The significant difference in $\mathrm{Ca}^{2+}$ and $\mathrm{Mg}^{2+}$ between growth stages can be ascribed to difference in growth requirements at two growth stages. However, difference between genotypes can be attributed to their survival mechanism under drought stress condition as reported earlier by Sardans et al. (2008). The higher level of $\mathrm{Mg}^{2+}$ at both stages of growth in drought sensitive genotype is attributed to the reduction in active transport and membrane permeability of cations resulting in their decreased absorption via roots ( $\mathrm{Hu}$ and Schmidhalter, 2005), and consequently their higher availability in rhizosphere. The significant differences in availability of $\mathrm{Fe}$ and $\mathrm{K}$ at two stages in both genotypes is attributed to varied physiological requirements of two stages of plant growth. However, the increased level of $\mathrm{Mn}$ from booting to anthesis stage only in drought tolerant genotype is attributed to the unique rhizospheric activities of drought tolerant genotype, and drought induced deficiency of $\mathrm{Mn}, \mathrm{Fe}$ and $\mathrm{Mo}$ in plants (Hu and Schmidhalter, 2005).The higher availability of nitrogen in rhizosphere of drought tolerant genotype can be ascribed to higher metabolic activities of tolerant genotype (Sairam, 1994). Further, the availability of nutrients in rhizosphere of drought tolerant genotypes, and their uptake as well as translocation is correlated with up-regulation of genes responsible for macro- and micronutrients uptake and translocation, and primary metabolic products like sugars, proteins, amino acids and prolines (Sallam et al., 2019). It leads to better survival of nutrient-efficient genotypes under stress conditions (Sallam et al., 2019).

Root exudates released under stress conditions can serve both as a food source and chemo-attractant for microbes (Jha et al., 2012). In the present study, the contrasting genotypes for two stresses varied for abundance of specific PGPRs and also exhibited significant interaction between stages of growth and genotypes. The relative abundance of 
different PGPRs was higher at anthesis in drought tolerant genotype compared to sensitive genotype. The present results can be corroborated with the results of Marschner et al. (2006), wherein, they reported varied rhizosphere microbial community composition among Poaceae genotypes, which changed during stages of growth. Similary, Qiao et al. (2017) also recorded the changes in structure of rhizosphere bacteria during different developmental stages. The role of host genetics in controlling the microbiome of the rhizosphere has also been reported by Berlanas et al. (2019) in mature vineyard, and have further advocated to understand interactions between microbiota and their hosts' plants, and their incorporation into plant breeding programs for ameliorating the adverse effects of abiotic stress conditions. The host genotype influences the keystone microbes, which then pass on their effect on total microbiome by changing microbe-microbe interaction and plant fitness. This response of plant genotype can be attributed to the nutrients preferences of the plants (Dastogeer et al., 2020). The modern wheat varieties are richer and even in bacterial communities with no or minimal effect of inputs on microbial diversity compared with ancient varieties (Jacquiod et al., 2021).

The contrasting genotypes for heat and drought stress tolerance, and two growth stages exhibited differential responses for their rhizosphere chemical constituents and abundance of PGPRs. The genotypes interacted differentially with stage of growth, as heat tolerance related genotypes showed significant interaction for $\mathrm{Na}^{+}, \mathrm{K}^{+}$and nitrogen, while drought tolerance genotypes for nitrogen only. The information can be exploited for making selection of stress tolerant wheat genotypes and managing the growth conditions under abiotic stress situations.

\section{Add-on Information}

Author's contribution : O.P. Ahlawat: Research, drafting and editing; T. Chugh: Research; K. Venkatesh: Statistical analyses and editing; R. Tiwari: Drafting and editing; P. Sharma, S. Sheoran, R. Singh, G. Singh, G.P. Singh: Editing; H.M. Mamrutha: Research and editing; N.K. Arora: Soil analysis.

Research content : The research content of manuscript is original and has not been published elsewhere.

Ethical approval: NotApplicable

Conflict of interest : The authors declare that there is no conflict of interest.

\section{Data from other sources : NotApplicable}

Consent to publish : All authors agree to publish the paper in Journal of Environmental Biology.

\section{Acknowledgments}

The authors thank SERB-DST, New Delhi for financial support and director, ICAR-Central Soil Salinity Research Institute, Karnal, India for extending help in rhizospheric soil samples analysis.

\section{References}

Berlanas, C., M. Berbegal,G. Elena, M. Laidani, J.F. Cibriain, A. Sagües and D. Gramaje: The fungal and bacterial rhizosphere microbiome associated with grapevine rootstock genotypes in mature and young vineyards. Front. Microbiol., 10, 1142 (2019).

Bhargava, G.P.: Training Manual for Undertaking Studies on Genesis of Sodic/Alkali Soils. Division of Soil and Crop Management, ICARCSSRI, Karnal, India (2003).

Brasil, E.C., V.M.C. Alves, I.E. Marriel, G.V.E. Pitta and J.G. de Carvalho: Rhizosphere properties of maize genotypes with contrasting phosphorus efficiency. Rev. Bras. Ciênc. Solo, 35, 171-181 (2011).

Chesnin, L. and C.H. Yien: Turbidimetric determination of available sulphate. Soil Sci. Soc. Am. Proc., 15, 149-151 (1950).

Danhorn, T. and C. Fuqua: Biofilm formation by plant-associated bacteria. Ann. Rev. Microbiol., 61, 401-422 (2007).

Dastogeer, K.M.G., F.H. Tumpa, A. Sultana, M.A. Akter and A. Chakraborty: Plant microbiome-an account of the factors that shape community composition and diversity. Curr. Plant Biol., 23, 100161 (2020). https://doi.org/10.1016/j.cpb.2020.100161.

Gee, G.W. and J.W. Bauder: Particle-size analysis.In: Methods of Soil Analysis, Part 1. Physical and Mineralogical Methods, Agronomy Monograph No. 9, $2^{\text {nd }}$ Edn. (Eds.: A. Klute). American Society of Agronomy/Soil Science Society of America, Madison, WI, 383 pages (1986).

Gontia-Mishra, I., S. Sapre, A. Sharma and S. Tiwari: Amelioration of drought tolerance in wheat by the interaction of plant growthpromoting rhizobacteria. Plant Biol., 18, 992-1000 (2016).

$\mathrm{Hu}, \mathrm{Y}$. and U. Schmidhalter: Drought and salinity: A comparison of their effects on mineral nutrition of plants. J. Plant Nutr. Soil Sci., 168, 541-549 (2005).

Jackson, M.L.: Soil Chemical Analysis. Prentice Hall of India Pvt. Ltd., New Delhi (1973).

Jha, B., I. Gontia and A. Hartmann: The roots of the halophyte Salicornia brachiata are a source of new halotolerant diazotrophic bacteria with plant growth promoting potential. Plant Soil, 356, 265-277 (2012).

Jones, D.L., C. Nguyen and R.D. Finlay: Carbon flow in the rhizosphere: Carbon trading at the soil-root interface. Plant Soil, 321, 5-33 (2009).

Jacquiod, S., T. Raynaud, E. Pimet, C. Ducourtieux, L. Casieri, D. Wipf and M. Blouin: Changes in wheat rhizosphere microbiota in response to chemical inputs, plant genotypes and phenotypic plasticity. BioRxiy (2021). https//doi.org/10.1101/2021.0.07. 441152

Kasim, W.A., M.E. Osman, M.N. Omar, I.A. Abd El-Daim, S. Bejai and J. Meijer: Control of drought stress in wheat using plant growth promoting bacteria.J. Plant Growth Regul., 32, 122-130 (2013).

Kaushal, M. and S.P. Wani: Plant growth-promoting rhizobacteria: drought stress alleviators to ameliorate crop production in dry lands. Ann. Microbiol., 66, 35-42 (2016).

Kuo, S.: Phosphorus. In: Methods of Soil Analysis, Part 3-Chemical 
Methods (Eds.: D.L. Sparks, A.L. Page, P.A. Helmke, R.H. Loeppert, P.N. Soltanpour, M.A. Tabatabai, C.T. Johnston and M.E. Sumner). American Society of Agronomy/Soil Science Society of America, Madison, WI, 869 pages (1996).

Lemanceau, P., M. Barret, S. Mazurier, S. Mondy, B. Pivato, T. Fort and C. Vacher: Plant communication with associated microbiota in the spermosphere, rhizosphere and phyllosphere. In: How Plants Communicate with their Biotic Environment (Eds.: G. Becard). Academic Press, Cambridge, MA, 101 pages (2017).

Lindsway, W.L. and W.A. Norvell: Development of DTPA soil test for zinc, Iron, manganese and copper. Soil Sci. Soc. Am. J., 42, 421-48 (1978).

Marschner, P., Z. Solaiman and Z. Rengel: Rhizosphere properties of Poaceae genotypes under P-limiting conditions. Plant Soil, 283, 11-24 (2006).

McNear, Jr., D.H.: The rhizosphere - roots, soil and everything in between. Plant Soil, 283,1 (2013).

Morrissey, J., J. Dow, G. Mark and F. O'Gara: Are microbes at the root of a solution to world food production? EMBO Rep., 5, 922-926 (2004).

Nelson, D.W. and L.E. Sommers: Total carbon, organic carbon, and organic matter. In: Methods of Soil Analysis, Part 3-Chemical Methods (Eds.: D.L. Sparks, A.L. Page, P.A. Helmke, R.H. Loeppert, P.N. Soltanpour, M.A. Tabatabai, C.T. Johnston and M.E. Sumner). American Society of Agronomy/Soil Science Society of America, Madison, WI, 961 pages (1996).

Philippot, L., J.M. Raaijmakers, P. Lemanceau and W.H. Van Der Putten: Going back to the roots: The microbial ecology of the rhizosphere. Nat. Rev. Microbiol., 11, 789-799 (2013).

Qiao, Q., F. Wang, J. Zhang, Y. Chen, C. Zhang, G. Liu, H. Zhang, C. Ma and J. Zhang: The variation in the rhizosphere microbiome of cotton with soil type, genotype and developmental stage. Sci. Rep., 7, 3940 (2017).

Rengel, Z.: Breeding crops for adaptation to environments with low nutrient availability. In: Abiotic Stresses: Plant Resistance Through Breeding and Molecular Approaches (Eds.: M. Ashraf and P.J.C. Harris). The Haworth Press, New York, 239 pages (2005).

Richards, L.A.: Diagnosis and Improvement of Saline-Alkali Soils. Agric. Hand Book 60 USDA, Washington D.C. (1954).

Sairam, R.K.: Effect of moisture stress on physiological activities of two contrasting wheat genotypes. Indian J. Exp. Biol., 32, 594-597 (1994).

Sallam, A., A.M. Alqudah, M.F.A. Dawood, P.S. Baenziger and A. Börner: Drought stress tolerance in wheat and barley: Advances in physiology, breeding and genetics research. Int. J. Mol. Sci.,20, 3137 (2019).

Sardans, J., J. Peñuelas and R. Ogaya: Drought's impact on Ca, Fe, Mg, $M o$ and $S$ concentration and accumulation patterns in the plants and soil of a Mediterranean evergreen Quercusilex forest. Biogeochem., 87, 49-69 (2008).

SAS Institute Inc.: SAS/STAT® 12.1 User's Guide. Cary, NC: SAS Institute Inc. (2012).

Walkley, A.J. and I.A. Black: An examination of the Degtjareff method for determining soil organic matter and proposed modification of the chromic acid titration method. Soil Sci., 37, 29-38 (1934).

Williams, C.H. and A. Steinbergs: Soil sulphur fractions as chemical indices of available sulphur in some Australian soils. Aust. J. Agric. Res.,10, 340-352 (1959).

Wilson, G.S.: The proportion of viable bacteria in young cultures with special reference to the technique employed in counting. $J$. Bacteriol., 7, 405-446 (1922). 